\title{
Profesyonel Turist Rehberlerinin İş Yaşam Dengelerinin Tükenmişlik ve Yaşam Doyumuna Olan Etkisi*
}

\section{The Effect of Professional Tourist Guides' Work Life Balance on Burnout and Life Satisfaction}

Arş. Gör. Öznur ÇETINKAYA

İstanbul Gelişim Üniversitesi

İktisadi, İdari ve Sosyal Bilimler Fakültesi, İstanbul,Türkiye

E-posta: ocetinkaya@gelisim.edu.tr
Prof. Dr. Füsun istANBULLU DiNÇER

İstanbul Üniversitesi, İktisat Fakültesi, İstanbul,Türkiye

E-posta: istanbul@istanbul.edu.tr

\section{Öz}

$\mathrm{Bu}$ araştırmanın amacl; profesyonel turist rehberlerinin iş yaşam dengelerini, tükenmişlik düzeylerini ve yaşam doyumlarını analiz ederek, aralarındaki iliş̧i ve etki durumunu ortaya koymaktır. Bu kapsamda, kartopu örnekleme yöntemi ile 302 adet anket toplanmış ve yapısal eşitlik modellemesi yapılarak değişkenler arasındaki ilişki durumu açıklanmıştır. Yapılan analizler neticesinde tükenmişliğin yaş gruplarına göre farklıık gösterdiği, yaşam doyumunun evli olan rehberlerde daha yüksek hissedildiği, iş yaşam dengesinin tükenmişlik üzerinde negatif, yaşam doyumu üzerinde pozitif etkisi olduğu belirlenmiştir.

Anahtar Kelimeler: Turist rehberliği, İ̧ yaşam dengesi, Tükenmişlik, Yaşam doyumu.

\section{Abstract}

The purpose of this research is to analyze the work life balance, burnout levels and life satisfaction of professional tourist guides, and to reveal the relationship between them. In this context, 302 questionnaires were collected with the snowball sampling method and the relationship between the variables was explained by performing structural equation modeling. As a result of the analysis, it was determined that burnout differs according to age groups, life satisfaction is felt higher in married guides, work-life balance has a negative effect on burnout and a positive effect on life satisfaction.

Key Words: Tourist guiding, Work life balance, Burnout, Life satisfaction.

*Bu makale Öznur Çetinkaya'nın "Profesyonel Turist Rehberlerinin Iş-Yaşam Dengesi ve Tükenmişlik Düzeylerinin Çalışma Motivasyonuna Etkisi" isimli doktora tezinden üretilmiştir. 


\section{Extended Summary}

\section{Purpose}

The main purpose of this research is to analyze the work life balance, burnout levels and life satisfaction of professional tourist guides and to reveal the relationship between them. Another purpose is to query if the scales means differs according to demographic variables or not.

\section{Background}

\section{Work Life Balance}

There are different approaches to define the work-life balance. While Guest (2002) defines "having time to fulfill the requirements of both work and private life", "Perceived balance between work and the rest of life", "Satisfaction achieved by entering into a minimum role conflict between work and home", Rama Devi and Nagini (2013) explained that work-life balance is not related to work or non-work time, it should be understood as spending time in one area and loading energy for the other.

\section{Burnout}

The concept of burnout was first stated by Freudenberger in his study in 1975 as "emotional exhaustion, which means that people become unable to fulfill the requirements of their work as a result of their excessive work" and "the state of exhaustion of the individual's internal resources as a result of failure, wear, loss of energy and power or unfulfilled requests". (Altay, 2009; Ergin, 1995; Ardıç \& Polatçı, 2009).

The feeling of burnout emerges as a result of the decrease in energy resources with the stress experienced by the person (Dalkılıç, 2014). Emotional labor and heavy workload cause individuals to feel exhausted (Hsieh et al., 2016).

\section{Life Satisfaction}

Life satisfaction is the evaluation of the quality of life with subjective criteria and the feeling of subjective well-being as a result of this evaluation. When people feel positive emotions and satisfaction with their lives, they enter into a high subjective well-being (Diener et al., 1985). Life satisfaction consists of six different components such as income level, work and social status, opportunities and sociality, welfare conditions, current state policy, environment, family and social relations (Appleton \& Song, 2008).

Productivity and professional life have great importance to ensure satisfaction in life (Ünal, Karlıdağ, \& Yoloğlu, 2001). Alrawadieh et al. (2018) revealed that the life satisfaction of tourist guides was positively related to their work life quality. In this case, the guide, who is satisfied in business life, will feel high in life satisfaction.

\section{Method}

302 questionnaires were collected with the snowball sampling method and the relationship between the variables was explained by performing structural equation modeling. The demographic distribution of the collected data was determined by performing frequency analysis. Afterwards, difference tests were performed and it was analyzed whether demographic features showed a difference on a scale basis. 
Skewness kurtosis values were analyzed for the purpose of fulfilling the condition of normal distribution and it was seen that the values were appropriate. Explanatory and confirmatory factor analyzes of the scales were performed and the adequacy of the sample was questioned by taking KMO values. Correlation analyzes were made between factor dimensions in order to find out whether there is a divergence between factor dimensions revealed as a result of factor analysis.

\section{Findings}

While work-life balance scale does not differ according to demographic variables, burnout is more intensely felt in participants between the ages of 20-35 (3,97). Life satisfaction was found to be higher $(5,03)$ among married tourist guides. As a result of the path analysis through structural equation modeling, it was determined that life balance has a negative effect on burnout and a positive effect on life satisfaction

\section{Results}

The guides' ability to balance work life, reduce the feeling of burnout and increase life satisfaction. If tourist guides have a balance between work and private life, they will be able to respond to the psychological needs of family, friends and will face less burnout. With the increase in the quality of the service provided, the guide will affect their own earnings and provide tourist satisfaction on behalf of the agency and will be instrumental in attracting more tourists to the country. For this reason, attention should be paid to balance while organizing tour programs of both guides and agencies, and guides should be able to spare time for themselves, their family and friends to reduce the feeling of burnout.

\section{Giriş}

Turist rehberliği, yapısı itibariyle farklı çalışma düzeni ve saatlerine sahiptir. Seyahat acenteleri tarafından düzenlenen turlar farklı şehirlerde, farklı saatlerde organize edilebilmekte ve tur süresi farklılık gösterebilmektedir. Hazırlanan paket turlar farklı sürelerle evden uzak kalmayı ya da bir sezon farklı bir destinasyonda kalmayı gerektirebilir. Çalışma saatleri turistlerin programına göre (transferler, balon turları, gece turları, Türk geceleri, özel organizasyonlar vb.) oluşturulduğundan esnek yapıdadır. Yoğun sezonda tur yoğunluğu, evden uzak olma, kendine vakit ayıramama, aile ve arkadaş ilişkilerinin olumsuz etkilenmesine ve kişinin yorgun hissetmesine, yıpranmasına neden olabilmektedir. Aksi durumda yaşanan bazı politik, ekonomik, sosyal krizler nedeniyle turizm talebinin düşmesi, tur sayısının azalması, rehberlerin hiç iş alamamasına ve iş ortamından uzak kalmasına neden olabilmektedir. İki durumda da iş yaşam dengenin sağlanması zor hale gelebilmektedir. Dengenin sağlanmaması halinde birey kendisini yorgun, yıpranmış ve tükenmiş hissedebilmektedir (Shukla ve Srivastava, 2016). İş yaşam dengesinin sağlanması ile tükenmişlik düzeyinin düşeceği (Kanwar, Singh ve Kodwani, 2009); tükenmişlik düzeyinin meslek hayatında edinilen doyumda önemli rol oynadığı, çalışma saatleri ve çalışma düzeni üzerinde kontrol sahibi olunmasının iş yaşam dengesi sağlanmasında ve tükenmişlik seviyesinde önemli bir gösterge olduğu (Keeton vd., 2007) açıklanmaktadır. Dengeli bir iş yaşamına sahip olan rehber, aile ve arkadaşlarının, kendi psikolojik ihtiyaçlarına cevap verebilecek ve tükenmişlik hissiyle daha az yüz yüze kalacaktır. Kendisini yoğun stres altında hisseden, yorgun ve tükenmiş hisseden bireyin yaşam doyumunun da etkileneceği öngörülmektedir. 
Bu çalışma ile profesyonel turist rehberlerinin iş yaşam dengelerinin, tükenmişlik düzeylerinin ve yaşam doyumlarının araştırılması amaçlanmıştır. İş yaşam dengesinin tükenmişliği ve yaşam doyumunu nasıl ve ne derece etkilediği sorgulanmıştır.

\section{Literatür Taraması}

\section{1.İş Yaşam Dengesi}

İş-yaşam dengesini tanımlamaya yönelik farklı yaklaşımlar bulunmaktadır. Guest (2002), "Hem iş hem özel hayatın gerekliliklerini yerine getirecek zamana sahip olma", "İ̧ ve hayatın geri kalanı arasında algılanan denge", "İ̧̧ ve ev arasında minimum rol çatışmasına girerek sağlanan memnuniyet" olarak tanımlarken, Rama Devi ve Nagini (2013), iş yaşam dengesinin iş veya iş dışı harcanan zamanla ilgili olmadığını, bir alanda vakit geçirirken diğer alan için enerji yüklenmesi olarak anlaşılması gerektiğini açıklamışlardır. Wong ve Ko (2009), iş yaşam dengesini, insanların çalışma düzenleriyle ilgili mekân ve zaman düzenlemesini yapabilmeleri, bireysel, toplumsal ve işe dair yararlara saygı duyulması olarak açıklamışlardır. İ̧̧ yaşam dengesinin sağlanması, çalışanın zaman kazanması, artan motivasyon ve üretkenlik, stresin ortadan kalkmasıyla düşen sağlık giderleri (Kanwar, Singh ve Kodwani, 2009), çalışan memnuniyeti ve bağlılığın sağlanmasında, üretken olunmasında (Putranti, 2018) önemli bir faktör olarak belirtilmektedir. İş ve yaşam alanları arasında çatışma yaşanması ise tükenmişlik hissine, psikolojik problemlere, aile ve arkadaş ilişkilerinin zarar görmesine neden olabilmektedir (Shukla ve Srivastava, 2016). İş yaşam dengesinin sağlanması amacıyla bireysel olarak sorun odaklı yaklaşım, duygu odaklı yaklaşım, rollerin paylaşımı, sosyal destek (Küçükusta, 2007), iş-aile rol sentezi (Yağcı,2014) gibi yaklaşımlar benimsenerek çözüm bulunabilmektedir. Örgütsel olarak, esnek çalışma düzeni (Yağcı, 2014), iş yaşam destek programları (Fairllie, 2004) ile iş yaşam dengesi kurulmasında fayda sağlanabilmektedir.

\subsection{Tükenmişlik}

Tükenmişlik kavramı ilk olarak Freudenberger tarafından 1975 yılındaki çalışmasında "insanların aşırı çalışmaları sonucu işlerinin gereklerini yerine getiremez bir duruma gelmeleri anlamını taşıyan duygusal tükenme" olarak belirtilmiş ve "başarısız olma, yıpranma, enerji ve güç kaybı veya karşılanamayan istekler sonucu bireyin iç kaynaklarında tükenme durumu" olarak açıklanmıştır (Altay, 2009; Ergin, 1995; Ardıç ve Polatçı, 2009).

Kişinin yaşadığı stresle birlikte enerji kaynaklarının azalması neticesinde tükenmişlik hissi ortaya çıkmaktadır (Dalkılıç, 2014). Duygusal emeğin ve iş yükünün yoğun olması bireylerin tükenmiş hissetmesine neden olmaktadır (Hsieh vd., 2016).

Christina Maslach modelinde tükenmişlik, duygusal tükenme, duyarsızlaşma ve kişisel başarı hissinde düşme olmak üzere üç boyuttan oluşur (Maslach, Schaufeli ve Leiter, 2001; Rutherford vd., 2011; Tümkaya, Çam ve Çavuşoğlu, 2009). Bu boyutlar birbiriyle ilişkili ancak birbirinden farklı olarak gelişmektedir (Ceyhan ve Siliğ, 2005). Stres kaynaklarıyla baş edemeyen birey önce duygusal tükenme hisseder. Duygusal tükenmeyle başa çıkmak içinse duyarsızlaşma boyutuna geçerek çevresiyle arasına mesafe koyarak, ilgisiz bir tutum takınır. Birey, duyarsızlaşma aşamasında çevresi veya işverenin beklentileriyle içinde bulunduğu durumun uyumsuz olduğunu hisseder ve kendini yetersiz görmeye başlayarak tükenmişliğin kişisel başarıda düşme hissi boyutuna geçer (Arı ve Bal, 2008). 
Tükenmişlik sonucunda aile yaşamı ve sosyal yaşamdaki ilişkiler negatif yönde etkilenmekte; kişinin üretkenliği, verimliliği düşmektedir (Ceyhan ve Siliğ, 2005). İş alanında ise, birey işten kendini geri çeker, işe gelmez, işten ayrılma niyetinde olur ve nihayetinde işten ayrılır (Maslach, Schaufeli ve Leiter, 2001). Tükenmiş birey, fiziksel olarak kendimi yorgun, gergin hissederek baş ağrısı, soğuk algınlığı, sindirim sistemi hastalıkları, kalp damar hastalıkları, deri hastalıkları gibi şikayetleri daha fazla yaşamaktadır (Ardıç ve Polatçı, 2009). Tükenmişlikle mücadele için bireysel olarak, gerçekçi hedefler belirlenmesi, çalışma stil ve düzeninin değiştirilmesi, iyimser bakış açısı geliştirme, sağlıklı beslenme ve spor yapma gibi öneriler sunulurken örgütlerin de doğru personel seçimi yapması, personel güçlendirmesi, iş zenginleştirme, sosyal destek programları, çeşitli eğitim ve seminerler ile personeline destek olması beklenmektedir (Dalkılıç, 2014).

\subsection{Yaşam Doyumu}

Doyum, beklentilerin gerçeklerle uyuşması ve isteklerin karşılanması durumudur (Avşaroğlu, Deniz ve Kahraman, 2005). Yaşam doyumu, yaşama gösterilen duygusal tepkidir (Dikmen, 1995); yaşamda farklı açılardan iyi olma hali ve olumlu duyguların hissedilmesidir (Avşaroğlu, Deniz ve Kahraman, 2005).

Yaşam doyumu öznel ölçütlerle yaşam kalitesinin değerlendirilmesi ve bu değerlendirme sonucu öznel iyi oluş hissedilmesidir. Kişiler olumlu duygular hissettiklerinde ve yaşamlarından memnun olduklarında yüksek bir öznel iyi oluş hali içerisine girmektedirler (Diener vd., 1985). Yaşam doyumu gelir düzeyi, iş ve sosyal statü, sahip olunan imkanlar ve sosyallik, refah koşulları, mevcut devlet politikası, çevre, aile ve sosyal ilişkiler gibi altı farklı bileşenden oluşmaktadır (Appleton ve Song, 2008).

Yaşamda doyum sağlamak için üretkenlik ve meslek hayatı büyük önem taşımaktadır (Ünal, Karlıdağ ve Yoloğlu, 2001). Doyum sağlayamayan birey, yoksunluk hisseder (Kara, Kelecek ve Aşçı, 2014) ve tükenmiş hissetmeye yatkın halde olur (Ünal, Karlıdağ ve Yoloğlu, 2001). Alrawadieh vd. (2018) yaptıkları çalışmada turist rehberlerinin yaşam doyumlarının iş yaşam kaliteleri ile pozitif şekilde ilişki olduğunu ortaya koymuşlardır. Bu durumda iş yaşamında memnun olan rehber, yaşam doyumunu da yüksek hissedecektir.

Yapılan alan yazın taramasında iş-yaşam dengesi, tükenmişlik ve yaşam doyumu kavramlarına yönelik yapılmış çalışmalar incelenerek, bu kavramların birbirleriyle olan teorik altyapısı ele alınmıştır. Tuğsal (2017), özel yaşamlarına zaman ayıramayan çalışanların tükenmişlik düzeylerinin arttığını; iş ve aile yaşamlarının olumsuz etkilenebildiğini belirtmektedir. Yağcı (2014), iş yaşam gelişimi olumsuz etkilenen çalışanın, iki alan arasında denge kuramaması nedeniyle tükenmişlik sendromunu ileri düzeyde yaşayabileceğini açıklamıştır. Taşdelen-Karçkay ve Bakalım (2017) yaptıkları çalışmada iş-aile çatışmasının iş yaşam dengesi aracılığıyla yaşam doyumu üzerinde dolaylı etkisinin olduğunu, iş yaşam dengesinin tükenmişlik üzerinde pozitif yönlü etkisinin olduğunu belirtmektedirler. Kuzulu, Kurtuldu ve Özkan (2013), iş yaşam çatışmasının yaşam doyumunu azalttığını; Haar vd. (2014) iş yaşam dengesinin iş ve yaşam doyumu ile pozitif yönlü ilişkisinin olduğunu; Cain, Busser and Kang (2018) ise işe dair çok büyük bir heves, aşk bile duyulsa iş ve yaşam alanları arasında denge sağlanmasının yaşam doyumuna ulaşmada önemli bir unsur olduğunu açıklamışlardır. Alrawadieh vd. (2020) ise rehberlerin çalışma hayatı kalitesi ile yaşam doyumu arasında pozitif bir ilişki olduğunu ortaya koymaktadır. Tükenmişlik ve yaşam doyumu arasındaki ilişkiyi inceleyen çalışmalar (Ünal, Karlıdağ ve Yoloğlu, 2001; Pınar vd., 2015; Avşaroğlu, Deniz ve Kahraman, 2005; Demerouti, Bakker ve Bulters, 2004; 
Chan, 2011) tükenmişlik düzeyi yüksek olan kişilerin yaşam doyumunun da negatif yönlü etkileneceğini ortaya koymuşlardır.

Yapılan alan yazın taraması ile araştırılması planlanmış hipotezler şu şekilde oluşturulmuştur:

- "H1: Profesyonel turist rehberlerinin iş-yaşam dengesinin tükenmişlik düzeyleri üzerinde etkisi vardır"

- "H2: Profesyonel turist rehberlerinin tükenmişlik düzeylerinin yaşam doyumu üzerinde etkisi vardır"

- "H3: Profesyonel turist rehberlerinin iş-yaşam dengelerinin yaşam doyumları üzerinde etkisi vardır"

\section{Yöntem}

$\mathrm{Bu}$ araştırmada iş yaşam dengesini ölçmek için Brough ve arkadaşları (2014)'nın geliştirdiği 4 ifadeli ölçek kullanılmıştır. Tükenmişliği ölçmek için, Maslach ve Jackson (1981) orijinal ölçeği kullanılarak, Türkçeye çevrilmiştir. Literatürde en bilinen tükenmişlik ölçeği Maslach ve Jackson tarafından 1981 yılında geliştirilmiş tükenmişlik ölçeğidir. Maslach ve Jackson (1981) tükenmeyi duygusal tükenme, duyarsızlaşma ve kişisel başarı hissinde düşme olmak üzere 3 boyut altında, 22 ifade ile ölçmüşlerdir. Yaşam doyumunu ölçek için Diener ve arkadaşları tarafından 1985 yılında geliştirilmiş olan, beş ifadeli ölçek kullanılmış ve 7'li Likert ölçeği ile ölçülmüştür.

Profesyonel turist rehberlerine ulaşmak için olasılıklı olmayan örnekleme yöntemlerinden kartopu örnekleme yöntemi tercih edilmiştir. Kartopu örnekleme, zengin veri elde edilmesini sağlayacak kişi ve kurumlarla iletişime geçilerek onlar aracılığıyla anket formunun dağıtımının sağlanmasıdır. Zincir örnekleme de denilen bu teknikte, araştırmacı, örnekleme girmeye uygun olan kişileri bulup aynı ölçütte olan kişilere bu kişiler aracılığıyla ulaşmaya çalışır (Baltacı, 2018). Bu çalışmada kartopu örnekleme tekniği kapsamında rehberlik odaları ile iletişime geçilerek araştırma bilgisi verilmiş ve anket formunun eylemli üyelere iletilmesi rica edilmiştir. Bu sayede 302 adet anket geri dönüşü sağlanmıştır. Oluşturulan anket formu, 06/08/2020-103972 tarih ve sayılı İstanbul Üniversitesi Rektörlüğü Sosyal ve Beşerî Bilimler Araştırmaları Etik Kurul onayı ile bilimsel açıdan uygun bulunmuştur.

Teorik altyapının doğrulanmasıyla kuramsal olarak varlığı kurulmuş olan ilişkilerin veri ile uyumunu doğrulamak için yapısal eşitlik analizinin kullanılması uygundur (Meydan ve Şeşen, 2015). Literatür araştırması ile bu çalışmada teorik altyapı doğrulanmış ve yapısal eşitlik analizinin kullanılması öngörülmüştür.

Elde edilen verilerin analiz edilmesi için istatistik paket programları kullanılmıştır. Öncelikle kayıp veri kontrolü yapılmış, anketin çevrimiçi hazırlanması ve her sorunun zorunlu kılınması sebebiyle kayıp veri alınmamıştır. Sonrasında demografik veriler gruplandırılmış ve analize hazır hale getirilmiştir. İş-yaşam dengesi ölçeğinin ikinci ifadesi olan 'İşim ile iş dışı aktivitelerimi dengelemede zorluk yaşıyorum' ifadesi ters kodlama yapılmış, analize uygun hale getirilmiştir. Toplanan demografik verilerin frekans analizleri yapılarak, dağılımları belirtilmiştir. Sonrasında demografik verilerin ölçeklere göre ortalamaları alınarak, fark testleri yapılarak, ölçek bazında fark gösterip göstermedikleri analiz edilmiştir. Ölçek ifadelerinin analiz edilebilmesi için öncelikle 
normal dağılım sağlanması şartını yerine getirme maksatlı çarpıklık basıklık değerleri analiz edilmiş ve değerlerin uygun olduğu görülmüştür. Ölçeklerin güvenilirlik ve açıklayıcı faktör analizleri yapılmış ve KMO değerleri de alınarak, örneklemin yeterliliği sorgulanmıştır. Yapılan faktör analizi sonucu ortaya çıkan faktör boyutları arasında ayrışmanın olup olmadığının ortaya çıkarılması amacıyla faktör boyutları arasında korelasyon analizleri yapılmıştır.

\section{Bulgular}

Demografik verilere yönelik yapılmış frekans analizleri sonucunda, katılımcıların çoğunluğunu $(\% 60,9)$ erkeklerin oluşturduğu; medeni durumun yakın ortalamada (\%44,7-55,3) seyrettiği, eğitim düzeyinin çoğunlukla lisans seviyesinde olduğu $(\% 65,6)$, yaş grupları açısından 50 yaş altının araştırmaya daha fazla dahil olduğu $(\% 80,8)$, mesleki deneyim açısından mesleğe yeni başlamış 1 yıldan az deneyime sahip rehberlerin araştırmaya daha fazla $(\% 32,8)$ destek verdiği belirlenmiştir (Tablo1).

Tablo1: Demografik Bilgilerin Dağılımı

\begin{tabular}{ccc}
\hline & $\mathrm{n}$ & $\%$ \\
\hline Cinsiyet & 184 & 60,9 \\
Erkek & 118 & 39,1 \\
Kadın & 302 & 100,0 \\
Medeni Durum & 135 & \\
Bekar & 167 & 54,7 \\
Evli & 302 & 100,3 \\
& & \\
Eğitim Düzeyi & 198 & 65,6 \\
Lisans & 48 & 15,9 \\
Lisansüstü & 56 & 18,5 \\
Lise & 302 & 100,0 \\
& & \\
Yaş Grupları & 127 & 42,1 \\
$20-35$ & 117 & 38,7 \\
$36-50$ & 58 & 19,2 \\
$51-75$ & 302 & 100 \\
& & \\
Mesleki Deneyim & 99 & 32,8 \\
1 yıldan az & 33 & 10,9 \\
$1-5$ yıl & 52 & 17,2 \\
6-10 yıl & 57 & 18,9 \\
$11-20$ yıl & 61 & 20,2 \\
$21-45$ yıl & 302 & 100 \\
& &
\end{tabular}

Verilerin normal dağılımını test etmek amacıyla çarpıklık (skewness) basıklık (kurtosis) değerleri incelenmiş ve literatürde önerilen sınırlar içinde kalındığı görülmüştür. Çarpıklık-basıklık değerleri araştırmacılar tarafından farklı sınırlarda kabul görmüştür. Buna göre, Hair vd. (2013) değerlerin +1 ile -1 sınırları arasında kalmasını uygun görürken, Tabachnick ve Fidell (2013) değerlerin +1.5 ile -1.5 arasında kalmasını kabul etmiş, George ve Mallery (2010) ise belirtilen değerlerin +2 ile -2 arasında olmasını gerektiğini belirtmektedir (Tablo2). 
Tablo 2: Ölçek İfadelerinin Çarpıklık Basıklık Değerleri

\begin{tabular}{|c|c|c|c|c|}
\hline & Ortalama & Std. Sapma & Çarpıklık & Basıklık \\
\hline \multicolumn{5}{|l|}{ İş-Yaşam Dengesi } \\
\hline $\begin{array}{l}\text { Şu anda işte harcadığım zaman ile } \\
\text { iş dışı aktivitelere ayırdığım zaman } \\
\text { arasında ivi bir dengeve sahibim. }\end{array}$ & 3,91 & 2,050 & 0,016 & $-1,340$ \\
\hline $\begin{array}{l}\text { İşim ile iş dışı aktivitelerimi } \\
\text { dengelemede zorluk yaşıyorum. }\end{array}$ & 3,88 & 1,980 & 0,097 & $-1,250$ \\
\hline 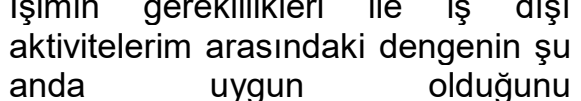 & 4,08 & 1,939 & $-0,072$ & $-1,187$ \\
\hline $\begin{array}{l}\text { düşünüyorum. } \\
\text { Genel anlamda, işim ile iş dışı } \\
\text { yaşantımın dengeli olduğuna } \\
\text { inanıyorum. }\end{array}$ & 4,31 & 1,952 & $-0,231$ & $-1,210$ \\
\hline \multicolumn{5}{|l|}{ Tükenmişlik } \\
\hline $\begin{array}{l}\text { Duygusal olarak işimde } \\
\text { hissediyorum. }\end{array}$ & 3,14 & 1,466 & 0,344 & $-0,640$ \\
\hline $\begin{array}{l}\text { İş gününün sonunda bitmiş } \\
\text { hissediyorum. }\end{array}$ & 3,69 & 1,699 & 0,049 & $-1,014$ \\
\hline $\begin{array}{l}\text { Sabah uyandığımda ve işte başka } \\
\text { bir gün daha geçirmek zorunda } \\
\text { olduğumda yorgun hissediyorum. }\end{array}$ & 2,91 & 1,528 & 0,534 & $-0,605$ \\
\hline $\begin{array}{l}\text { Bütün gün insanlarla çalışmak } \\
\text { benim için gerçekten bir zorlanma }\end{array}$ & 2,70 & 1,516 & 0,665 & $-0,490$ \\
\hline İşimden tükenmiş hissediyorum. & 2,67 & 1,592 & 0,853 & $-0,075$ \\
\hline $\begin{array}{l}\text { Işim yüzünden hüsrana uğramış } \\
\text { hissediyorum. }\end{array}$ & 2,10 & 1,406 & 1,194 & 0,488 \\
\hline $\begin{array}{l}\text { Çok yoğun } \quad \text { çalıştığımı } \\
\text { düşünüyorum. }\end{array}$ & 3,91 & 1,864 & 0,049 & $-1,126$ \\
\hline $\begin{array}{l}\text { Direkt olarak insanlarla çalışmak } \\
\text { bana çok fazla stres yüklüyor. }\end{array}$ & 3,16 & 1,701 & 0,551 & $-0,622$ \\
\hline $\begin{array}{l}\text { Sabrımın sınırına } \\
\text { düşünüyorum. }\end{array}$ & 2,46 & 1,478 & 1,083 & 0,631 \\
\hline $\begin{array}{l}\text { Müşterilerin bir şeyler hakkında } \\
\text { nasıl hissettiklerini } \\
\text { anlayabilirim. }\end{array}$ & 5,68 & 1,123 & $-1,092$ & 1,441 \\
\hline $\begin{array}{l}\text { Müşterilerin problemleri ile çok etkili } \\
\text { şekilde başa çıkarım. } \\
\text { İşim aracılığıyla başkalarının }\end{array}$ & 5,83 & 1,057 & $-1,085$ & 1,475 \\
\hline $\begin{array}{l}\text { hayatını pozitif olarak etkilediğimi } \\
\text { düşünüyorum. }\end{array}$ & 5,86 & 1,204 & $-1,329$ & 2,189 \\
\hline Çok enerjik hissediyorum. & 5,30 & 1,257 & $-0,655$ & 0,264 \\
\hline $\begin{array}{l}\text { Müşterilerimle kolayca rahat bir } \\
\text { atmosfer oluşturabilirim. }\end{array}$ & 5,99 & 0,998 & $-1,237$ & 2,382 \\
\hline $\begin{array}{l}\text { Müşterilerimle yoğun bir gün } \\
\text { geçirdikten sonra iyi hissederim. }\end{array}$ & 5,66 & 1,220 & $-0,937$ & 0,644 \\
\hline $\begin{array}{l}\text { Mesleğimde birçok kayda değer şey } \\
\text { başardım. }\end{array}$ & 5,53 & 1,301 & $-1,110$ & 1,304 \\
\hline $\begin{array}{l}\text { İşimde, duygusal problemlerle } \\
\text { soğukkanlı şekilde başa çıkarım. }\end{array}$ & 5,79 & 1,206 & $-1,228$ & 1,510 \\
\hline
\end{tabular}


Tablo 2'nin devamı

Bazı müşterilere sanki insan değil "somut varlıklar" gibi davrandığımı hissediyorum.

$\mathrm{Bu}$ işe başladığımdan beri insanlara karşı duyarsızlaştım.

$\mathrm{Bu}$ işin beni duygusal olarak zorladığından kaygılanıyorum.

$2,38 \quad 1,574 \quad 1,078 \quad 0,362$

$\begin{array}{llll}2,18 & 1,497 & 1,265 & 0,726\end{array}$

$\begin{array}{llll}2,66 & 1,562 & 0,654 & -0,564\end{array}$

$\begin{array}{llll}2,38 & 1,642 & 1,143 & 0,352\end{array}$ gerçekten umursamıyorum.

$3,06 \quad 1,669 \quad 0,511 \quad-0,689$

Müşterilerin problemlerinin bazıları için beni suçladığını hissediyorum.

Yaşam Doyumu

Çoğu açıdan hayatım olması gerekene yakındır.

Yaşam koşullarım mükemmeldir.

Hayatımdan memnunum.

Şimdiye kadar hayatımda istediğim önemli şeylere sahip oldum

Eğer hayatımı baştan yaşayabilseydim, neredeyse hiçbir şeyi değiştirmezdim.

$\begin{array}{llll}5,03 & 1,431 & -0,764 & 0,455 \\ 4,43 & 1,412 & -0,674 & -0,118 \\ 5,39 & 1,337 & -1,114 & 1,117 \\ 5,24 & 1,396 & -0,727 & 0,036 \\ & & & \\ 4,42 & 1,822 & -0,379 & -0,801\end{array}$

Demografik değişkenlere göre iş-yaşam dengesi, tükenmişlik ve yaşam doyumu ölçeklerinde farklılık oluşup oluşmadığının kontrolü için iki gruplu değişkenlerde bağımsız örneklem t-Testi, üç veya daha fazla gruplu değişkenler için Anova analizi yapılmıştır. Öncelikle ölçek ifadelerinin gruplara göre ortalamaları verilerek hangi grubun yüksek hangi grubun düşük puanlı cevap verdiği belirlenmiştir. Yapılan t-Testi ve Anova analiz değerleri ve anlamlılık değeri $(p)$ verilmiştir. Buna göre iş yaşam dengesi ölçeği gruplara göre farklılık göstermezken, tükenmişlikte yalnızca yaş grubunda fark görülmüştür. Buna göre yaş gruplarına göre tükenmişlik düzeyinin az da olsa farklılık gösterdiğini belirtmek mümkündür. 20-35 arası yaş aralığındaki turist rehberleri tükenmişliği daha yoğun hissetmekte $(3,97), 36-50$ yaş aralığındakiler $(3,80)$ ve 51-75 yaş aralığındakiler $(3,76)$ daha düşük hissetmektedirler (Tablo3).

Tablo 3: Demografik Değişkenlerin Ölçeklere Göre Fark Analizleri

\begin{tabular}{|c|c|c|c|c|c|c|}
\hline Ölçekler & \multicolumn{2}{|c|}{ Bireysel Özellikler } & $\overline{\mathbf{x}}$ & S.S. & $\mathbf{F} / \mathbf{t}$ & $\mathbf{P}$ \\
\hline \multirow{11}{*}{ 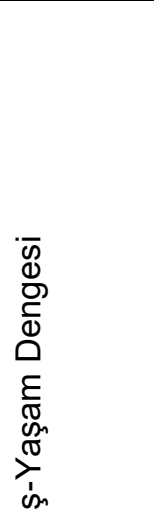 } & \multirow{3}{*}{ Cinsiyet } & Erkek & 4,02 & 1,67 & \multirow{3}{*}{0,170} & \multirow{3}{*}{0,865} \\
\hline & & & & & & \\
\hline & & Kadın & 4,06 & 1,69 & & \\
\hline & \multirow{2}{*}{$\begin{array}{l}\text { Medeni } \\
\text { Durum }\end{array}$} & Bekar & 3,97 & 1,64 & \multirow{2}{*}{0,608} & \multirow{2}{*}{0,544} \\
\hline & & Evli & 4,09 & 1,70 & & \\
\hline & \multirow{3}{*}{$\begin{array}{l}\text { Eğitim } \\
\text { Düzeyi }\end{array}$} & Lisans & 3,96 & 1,65 & \multirow{3}{*}{0,989} & \multirow{3}{*}{0,373} \\
\hline & & Lisansüstü & 4,34 & 1,77 & & \\
\hline & & $\begin{array}{c}\text { Önlisans } \\
\text { veya Lise }\end{array}$ & 4,04 & 1,64 & & \\
\hline & \multirow{3}{*}{ Yaş } & $20-35$ & 3,89 & 1,65 & \multirow{3}{*}{1,38} & \multirow{3}{*}{0,252} \\
\hline & & $36-50$ & 4,05 & 1,72 & & \\
\hline & & $51-75$ & 4,34 & 1.61 & & \\
\hline
\end{tabular}


Tablo 3'ün devamı

\begin{tabular}{|c|c|c|c|c|c|c|}
\hline & \multirow{5}{*}{$\begin{array}{l}\text { Mesleki } \\
\text { Deneyim }\end{array}$} & 1 yıldan az & 4,01 & 1,71 & \multirow{5}{*}{0,287} & \multirow{5}{*}{0,886} \\
\hline & & $1-5 \mathrm{yll}$ & 3,81 & 1,87 & & \\
\hline & & 6-10 yıl & 4,07 & 1,40 & & \\
\hline & & $11-20$ yıl & 4,02 & 1,72 & & \\
\hline & & $21-45$ yıl & 4,19 & 1,70 & & \\
\hline \multirow{16}{*}{ 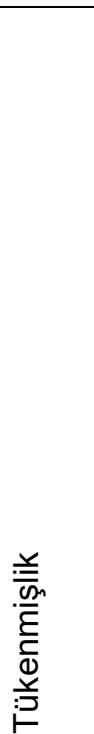 } & \multirow[t]{3}{*}{ Cinsiyet } & Erkek & 3,87 & 0,634 & \multirow{3}{*}{$-0,359$} & \multirow{3}{*}{0,720} \\
\hline & & & & & & \\
\hline & & Kadın & 3,84 & 0,631 & & \\
\hline & \multirow{2}{*}{$\begin{array}{l}\text { Medeni } \\
\text { Durum }\end{array}$} & Bekar & 3,92 & 0,632 & \multirow[b]{2}{*}{$-1,50$} & \multirow{2}{*}{0,133} \\
\hline & & Evli & 3,81 & 0,630 & & \\
\hline & \multirow{3}{*}{$\begin{array}{l}\text { Eğitim } \\
\text { Düzeyi }\end{array}$} & Lisans & 3,91 & 0,621 & \multirow{3}{*}{1,76} & \multirow{3}{*}{0,173} \\
\hline & & Lisansüstü & 3,78 & 0,602 & & \\
\hline & & $\begin{array}{l}\text { Önlisans } \\
\text { veya Lise }\end{array}$ & 3,75 & 0,686 & & \\
\hline & \multirow{3}{*}{ Yaş } & $20-35$ & 3,97 & 0,618 & \multirow{3}{*}{3,11} & \multirow{3}{*}{$0,046^{*}$} \\
\hline & & $36-50$ & 3,80 & 0,558 & & \\
\hline & & $51-75$ & 3,76 & 0,767 & & \\
\hline & \multirow{5}{*}{$\begin{array}{l}\text { Mesleki } \\
\text { Deneyim }\end{array}$} & 1 yıldan az & 3,84 & 0,604 & \multirow{5}{*}{2,22} & \multirow{5}{*}{0,066} \\
\hline & & $1-5 \mathrm{yıl}$ & 4,15 & 0,564 & & \\
\hline & & $6-10 \mathrm{yll}$ & 3,85 & 0,595 & & \\
\hline & & $11-20 \mathrm{yll}$ & 3,84 & 0,664 & & \\
\hline & & $21-45 \mathrm{yll}$ & 3,76 & 0,685 & & \\
\hline \multirow{16}{*}{ 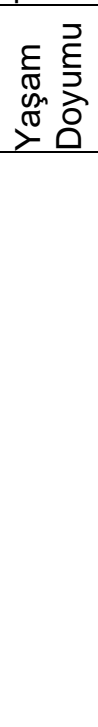 } & \multirow[t]{3}{*}{ Cinsiyet } & Erkek & 4,92 & 1,09 & \multirow{3}{*}{$-0,374$} & \multirow{3}{*}{0,708} \\
\hline & & & & & & \\
\hline & & Kadın & 4,86 & 1,39 & & \\
\hline & \multirow{2}{*}{$\begin{array}{l}\text { Medeni } \\
\text { Durum }\end{array}$} & Bekar & 4,73 & 1,27 & \multirow{2}{*}{2,11} & \multirow{2}{*}{$0,035^{\star}$} \\
\hline & & Evli & 5,03 & 1,15 & & \\
\hline & \multirow{3}{*}{$\begin{array}{l}\text { Eğitim } \\
\text { Düzeyi }\end{array}$} & Lisans & 4,86 & 1,16 & & \\
\hline & & Lisansüstü & 5,17 & 1,28 & & \\
\hline & & $\begin{array}{l}\text { Önlisans } \\
\text { veya Lise }\end{array}$ & 4,78 & 1,33 & 1,53 & 0,217 \\
\hline & & $20-35$ & 4,79 & 1,09 & & \\
\hline & Yaş & $36-50$ & 5,04 & 1,18 & 1,35 & 0,259 \\
\hline & & $51-75$ & 4,84 & 1,51 & & \\
\hline & & 1 yıldan az & 4,81 & 1,20 & & \\
\hline & $M$ & $1-5 \mathrm{yll}$ & 4,52 & 1,21 & & \\
\hline & MleslekI & 6-10 yıl & 4,94 & 0,96 & 1,42 & 0,224 \\
\hline & & $11-20 \mathrm{yll}$ & 5,09 & 1,20 & & \\
\hline & & 21-45 yıl & 5,02 & 1,43 & & \\
\hline
\end{tabular}

${ }^{*} p<0,05$ düzeyinde anlamlıdır.

İş yaşam dengesi ölçeğinin açıklayıcı faktör analizi yapılmış ve tek boyutlu yapının olduğu görülmüştür (Tablo4). Ölçek, Brough vd. (2014)'den alınmış ve literatürdeki yapısının bu araştırmada da aynı şekilde ortaya çıktığı görülmüştür. Ölçeğin toplam varyans açıklama oranı \%71,930'dur. Bu oranın iş yaşam dengesi kavramını açıklamada yüksek bir oran olduğunu belirtmek mümkündür. İfadelerin faktör yükleri ise 0,75 'in üzerindedir. Comrey ve Lee (1992)'ye göre faktör analizinde faktör yükleri 0,71 'in üzerinde harika, 0,63 'ün üzerindeyse çok iyi, 0,55 'in üzeri ise iyi olarak belirtilmektedir. Cronbach's Alpha güvenilirlik analiz sonucu da $(0,868)$ ölçeğin güvenilir olduğunu (Cortina, 1993); KMO değeri $(0,803)$ ölçüm yapmada örneklemin 
yeterli olduğunu (Tabachnick ve Fidell, 2001) göstermektedir. Bartlett Küresellik Testi ise, değişkenler arasında ilişkinin anlamlı $(p<0,05)$ olduğunu göstermektedir (Büyüköztürk, 2011).

Tablo 4: İş Yaşam Dengesi Faktör Analizi

Faktör Yükleri

Genel anlamda, işim ile iş dışı yaşantımın dengeli olduğuna inanıyorum.

0,882

Şu anda işte harcadığım zaman ile iş dışı aktivitelere ayırdığım zaman arasında iyi bir dengeye sahibim.

İşimin gereklilikleri ile iş dışı aktivitelerim arasındaki dengenin şu anda uygun olduğunu düşünüyorum.

İşim ile iş dışı aktivitelerimi dengelemede zorluk yaşıyorum.

Toplam Varyans Açıklama Oranı

Cronbach's Alpha

$\mathrm{KMO}$

Bartlett Küresellik Testi

0,803

$620,586 /, 000$

Tükenmişlik ölçeğinin açıklayıcı faktör analizi sonucunda, faktör yapısının Maslach ve Jackson (1981) orijinal ölçeği ile uyum gösterdiği görülmüştür (Tablo5). Literatürdeki ölçek yapısı gibi bu araştırmada da üç boyutlu bir yapı ortaya çıkmıştır. Varimax döndürme yöntemi kullanılarak analiz gerçekleştirilmiş ancak 7.ifade olan 'Çok yoğun çalıştığımı düşünüyorum' ifadesi diğer faktörlere bulaşık olması ve faktör yükünün düşük kalması sebebiyle analizden çıkarılmıştır. Ifade çıkartıldıktan sonra analiz tekrar edilmiştir. İlk faktör duygusal tükenme boyutunu ifade etmekte, ikinci boyut kişisel başarıda düşme, üçüncü boyut ise duyarsızlaşma boyutunu açıklamaktadır. İlk faktör olan duygusal tükenme toplam varyansın \%36,415'ini açıklamakta; ikinci boyut olan kişisel başarıda düşme hissi toplam varyansın $\% 15,261$ 'ini açıklamakta; üçüncü faktör olan duyarsızlaşma toplam varyansın $\% 6,285$ 'ini açıklamaktadır. Bu durumda tükenmişlik ölçeğinde en etkili ve öne çıkan boyutun birinci boyut olan duygusal tükenme boyutu olduğunu belirtmek mümkündür.

Tablo 5: Tükenmişlik Ölçeği Açıklayıcı Faktör Analizi

\begin{tabular}{lccc}
\hline & & Faktör Yükleri \\
& 1 & 2 & 3 \\
\hline İsimden tükenmiş hissediyorum. & 0,806 & & \\
I̧ş gününün sonunda bitmiş hissediyorum. & 0,758 & \\
Sabah uyandığımda ve işte başka bir gün & & \\
daha geçirmek zorunda olduğumda yorgun & 0,752 & \\
hissediyorum. & & \\
Bütün gün insanlarla çalışmak benim için & 0,691 & \\
gerçekten bir zorlanma & 0,667 & \\
Duygusal olarak işimde bitkin hissediyorum. & 0,661 & \\
Sabrımın sınırına geldiğimi düşünüyorum. & 0,650 & \\
Bu işin beni duygusal olarak zorladığından & & \\
kaygılanıyorum. & Issim yüzünden hüsrana uğramış & 0,636 & \\
hissediyorum. & & \\
Direkt olarak insanlarla çalışmak bana çok & 0,513 & \\
fazla stres yüklüyor. &
\end{tabular}




\section{Tablo 5'in devamı}

Müşterilerimle kolayca rahat bir atmosfer oluşturabilirim.

Müşterilerin problemleri ile çok etkili şekilde

başa çıkarım.

İşim aracılığıyla başkalarının hayatını pozitif olarak etkilediğimi düşünüyorum.

İşimde, duygusal problemlerle soğukkanlı

şekilde başa çıkarım.

Müşterilerimle yoğun bir gün geçirdikten

sonra iyi hissederim.

Müşterilerin bir şeyler hakkında nasıl

hissettiklerini kolayca anlayabilirim.

Mesleğimde birçok kayda değer şey

başardım.

Çok enerjik hissediyorum.

Bazı müşterilere sanki insan değil "somut varlıklar" gibi davrandığımı hissediyorum.

duyarsızlaştım.

Bazı müşterilere ne olduğunu gerçekten

umursamıyorum.

Müşterilerin problemlerinin bazıları için beni suçladığını hissediyorum.

\begin{tabular}{|c|c|c|c|}
\hline $\begin{array}{l}\text { Varyans } \\
\text { Toplam Varyans Açıklama Oranı } \\
\text { Cronbach's Alpha }\end{array}$ & 36,415 & 15,261 & $\begin{array}{l}6,285 \\
57,961 \\
0,788\end{array}$ \\
\hline $\mathrm{KMO}$ & & 0,914 & \\
\hline
\end{tabular}

Faktörleri oluşturan ifadelerin birbirleriyle uyumunu gösteren KMO değeri ,914; Bartlett küresellik testi sonucu anlamlı $(p<, 000)$ ve toplam güvenilirlik değeri olan Cronbach's Alpha 0,788 olarak bulunmuştur. Toplam varyans açıklama oranı $\% 57,961$ olarak hesaplanmış böylece tükenmişlik ölçeğine yönelik yapılmış olan açıklayıcı faktör analizinin anlamlı, geçerli sonuçlar ortaya koyduğu belirlenmiştir.

Tükenmişlik ölçeğine yönelik yapı geçerliliğinin sağlanması adına açıklayıcı faktör analizi haricinde ayrışma geçerliliği analizinin de yapılması uygun görülmüştür. Ayrışma geçerliliği, faktör boyutlarının kavramsal olarak birbirinden ayrılmasıdır (Nunnally, 1994 Akt: Yıldız, 2020). Ayrışma veya yakınsama analizi olarak adlandırılan analiz ile, faktör boyutları arası korelasyon analizi yapılarak boyutlar arasındaki ilişkinin düşük veya orta dereceli çıkması beklenir. Yakınsama ve ayrışma geçerliliği, faktör yapısının geçerliliğini ortaya koymaktadır (Kline, 2011). Yapılan ayrışma geçerliliği analizi sonucunda tükenmişlik ölçeği faktör boyutları arasında düşük $(-0,402 ;-0,309)$ ve orta dereceli $(0,607)$ ilişki olduğu görülmüş ve boyutların kavramsal olarak birbirinden ayrıldığı ortaya konmuştur (Tablo6). 
Tablo 6: Tükenmişlik Ölçeği Ayrışma Geçerliliği Sonuçları

\begin{tabular}{llccc}
\hline & & TT1 & TT2 & TT3 \\
\hline TT1 & Pearson Korelasyon & 1 & & \\
TT2 & Pearson Korelasyon & $-0,402^{*}$ & 1 & \\
TT3 & Pearson Korelasyon & $0,607^{*}$ & $-0,309^{*}$ & 1 \\
& $\mathrm{~N}$ & 302 & 302 & 302 \\
\hline
\end{tabular}

*Korelasyon 0.01 seviyesinde anlamlıdır.

Yaşam doyumu ölçeği açıklayıcı faktör analizi sonucu Diener vd. (1985) gibi tek boyutlu bir yapı ortaya çıkmıştır. Ölçeğin toplam varyans açıklama oranı \%68,749'dur. Cronbach Alpha güvenilirlik analiz sonucu $(0,877)$ ölçeğin güvenilir olduğunu; KMO değeri $(0,855)$ ölçüm yapmada örneklemin yeterli olduğunu göstermektedir. Bartlett Küresellik Testi ise, değişkenler arasında ilişkinin anlamlı $(p<0,05)$ olduğunu göstermektedir (Tablo7).

Tablo 7: Yaşam Doyumu Ölçeği Açıklayıcı Faktör Analizi

\section{Faktör}

Çoğu açıdan hayatım olması gerekene 0,868

yakındır.

Hayatımdan memnunum.

0,856

Şimdiye kadar hayatımda istediğim önemli şeylere sahip oldum.

Yaşam koşullarım mükemmeldir.

0,835

Eğer hayatımı baştan yaşayabilseydim, neredeyse hiçbir şeyi değiştirmezdim.

\begin{tabular}{lc}
\hline Toplam Varyans Açıklama Oranı & 68,749 \\
Cronbach's Alpha & 0,877 \\
KMO & 0,855 \\
Bartlett Küresellik Testi & $811,353 / 0,000$ \\
\hline
\end{tabular}

Tükenmişlik ölçeğine yönelik yapılmış olan doğrulayıcı faktör analizi sonucu çıkan değerler kabul edilebilir düzeyde görülmüş ve faktör yapısı doğrulanmıştır. Modelde, GFI ve NFI değerleri kabul edilebilir değer olan 0,90'ın hemen altında olsa dahi, Ki kare, serbestlik dereceleri ve RMSEA değerinin uygun olması nedeniyle, modelin kabul edilebilir olduğu belirlenmiştir (X2/sd: 2,45; GFI:0,88; NFI: 0,88; CFI: 0,92; RMSEA: 0,069). 


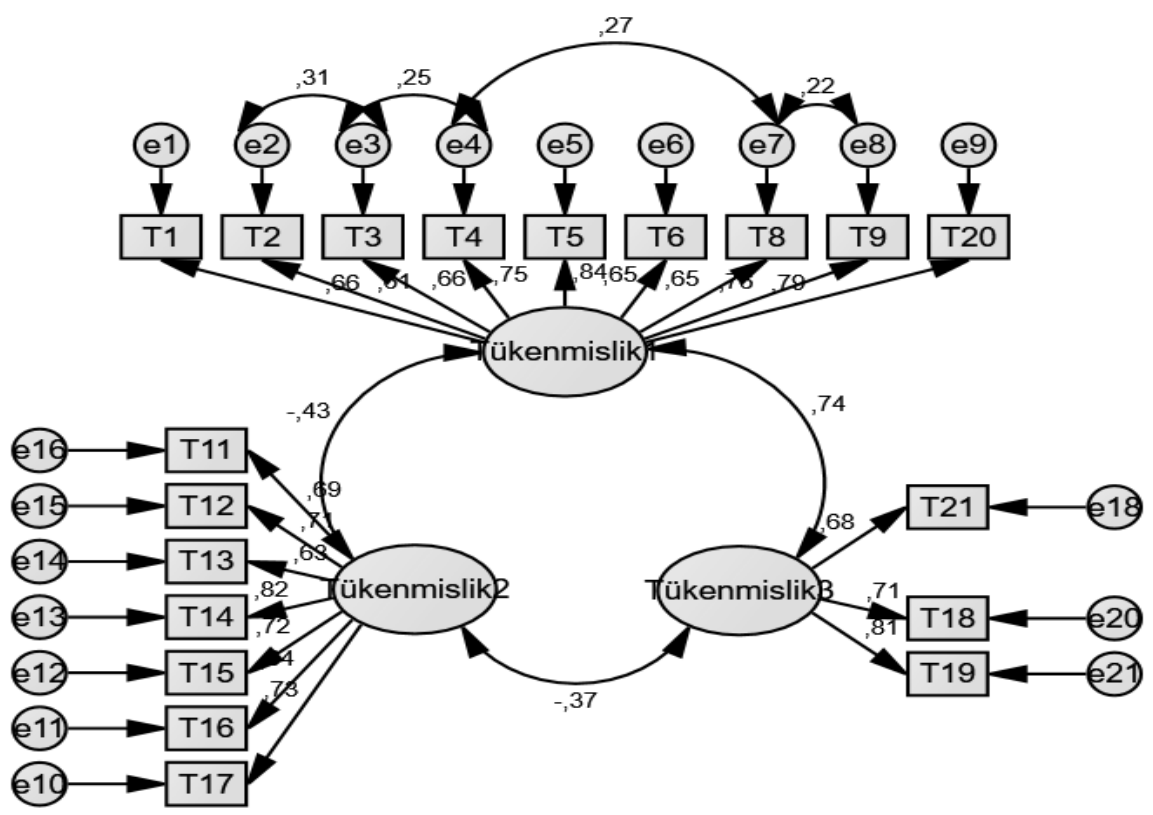

Şekil1: Tükenmişlik Ölçeği Doğrulayıcı Faktör Analizi

Tükenmişlik ölçeği doğrulayıcı faktör analizi sonucunda, 22.ifade olan 'Müşterilerin problemlerinin bazıları için beni suçladığını hissediyorum' ve 10. İfade olan 'Müşterilerin bir şeyler hakkında nasıl hissettiklerini kolayca anlayabilirim' analiz değerlerini düşürmeleri ve bulaşık değerlere sahip olmaları nedeniyle analizden çıkarılmışlardır. Değişkenler arasındaki değerler Şekil 1'de görülebilmektedir.

Profesyonel turist rehberlerinin iş yaşam dengesi ve tükenmişlik düzeylerinin yaşam doyumuna olan etkisinin araştırılması amacıyla oluşturulmuş araştırma modeline yönelik yapısal eşitlik modellemesi sonucu çıkan yol analizi Şekil 2'de görülmektedir. Modelin uyum değerleri ki kare nin serbestlik derecesi oranında kabul edilebilir, RMSEA değeri, CFI, GFI, NFI değerleri kabul edilebilir seviyede bulunmuştur (X2/sd: 2,387; GFI:0,93; NFI: 0,93; CFI: 0,96; RMSEA: 0,068). 


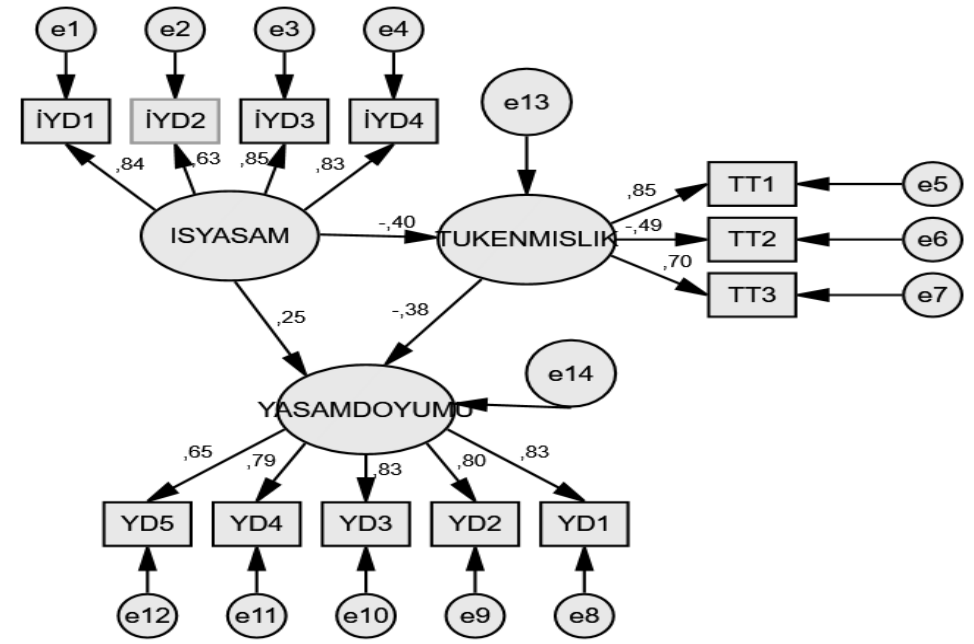

Şekil 2: Yol Analizi

Tablo 8: Araştırma Modeli Yol Analizi Değerleri

\begin{tabular}{|c|c|c|c|c|c|}
\hline & & & $\begin{array}{c}\text { Standart } \\
\text { Regresyon } \\
\text { Değerleri }\end{array}$ & Std. Hata & $p$ \\
\hline TÜKENMISLIKK & $<--$ & ISYASAM & $-0,403$ & 0,039 & $* * *$ \\
\hline YASAMDOYUMU & $<--$ & TÜKENMISLIKK & $-0,376$ & 0,089 & *** \\
\hline YASAMDOYUMU & $<--$ & ISYASAM & 0,253 & 0,046 & *** \\
\hline IYYD1 & $<--$ & ISYASAM & 0,842 & & \\
\hline IYY2 & $<--$ & ISYASAM & 0,634 & 0,062 & *** \\
\hline IYY3 & $<--$ & ISYASAM & 0,854 & 0,056 & $* * *$ \\
\hline IYY4 & $<--$ & ISYASAM & 0,832 & 0,057 & $* * *$ \\
\hline TT1 & $<--$ & TÜKENMISLIK & 0,853 & & \\
\hline TT2 & $<--$ & TÜKENMISLİK & $-0,488$ & 0,060 & *** \\
\hline TT3 & $<--$ & TÜKENMISLIKK & 0,696 & 0,098 & *** \\
\hline YD1 & $<--$ & YASAMDOYUMU & 0,832 & & \\
\hline YD2 & $<--$ & YASAMDOYUMU & 0,802 & 0,060 & *** \\
\hline YD3 & $<--$ & YASAMDOYUMU & 0,827 & 0,056 & *** \\
\hline YD4 & $<--$ & YASAMDOYUMU & 0,790 & 0,060 & *** \\
\hline YD5 & $<---$ & YASAMDOYUMU & $-0,646$ & 0,083 & *** \\
\hline
\end{tabular}


Yapısal eşitlik modellemesi ile yapılan yol analizi sonucu araştırma modeli kapsamında oluşturulmuş hipotezlerden "H1: Profesyonel turist rehberlerinin iş-yaşam dengesinin tükenmişlik düzeyleri üzerinde etkisi vardır" hipotezi kabul edilmiştir. İş yaşam dengesinin tükenmişlik üzerinde negatif yönlü $(-0,403)$ etkisi bulunmaktadır. "H2: Profesyonel turist rehberlerinin tükenmişlik düzeylerinin yaşam doyumu üzerinde etkisi vardır" hipotezi kabul edilmiştir. Tükenmişlik düzeyinin yaşam doyumu üzerinde negatif yönlü $(-0,376)$ etkisi bulunmaktadır. "H3:Profesyonel turist rehberlerinin işyaşam dengelerinin yaşam doyumları üzerinde etkisi vardır" hipotezi kabul edilmiştir. İş yaşam dengesinin yaşam doyumu üzerinde pozitif yönlü $(0,253)$ etkisi bulunmaktadır.

Analizler sonucunda ölçeklerin demografik özelliklere göre farkları incelendiğinde iş yaşam dengesi ölçeği gruplara göre farklılık göstermezken, tükenmişlikte yalnızca yaş grubunda fark görülmüş; evli olan turist rehberlerinin yaşam doyumunun daha yüksek olduğu saptanmıştır. Ölçeklerin faktör yapıları literatürdeki orijinal faktör yapıları ile uyumluluk göstermiş ve geçerli oldukları belirlenmiştir. Değişkenlerin ilişki yapısını ortaya koymak için yapılan yapısal eşitlik modellemesi ile bütün gözlenen ve gizil değişken ilişkilerinin anlamlı çıktığı belirlenmiştir.

\section{Sonuç ve Öneriler}

Bu çalışma ile profesyonel turist rehberlerinin iş yaşam dengeleri, tükenmişlik düzeyleri ve yaşam doyumları araştırılmış ve aralarındaki ilişki ve etki durumu ortaya konmuştur. İş yaşam, tükenmişlik ve yaşam doyumu kavramlarının turist rehberliği mesleği ile ilişkisi göz önüne alındığında, çalışma alana katkı sağlamaktadır.

Demografik bilgiler analiz edildiğinde, araştırmaya veri sağlayan katılımcıların çoğunu erkeklerin $(\% 60,9)$ oluşturduğu ve katılımcıların $\% 80,8$ gibi büyük bir oranının 50 yaş altında olduğu görülmektedir. Ölçek analizlerine geçmeden önce normallik dağılımını görmek için çarpıklık ve basıklık değerleri incelenmiş ve literatürde belirtilen değerler arasında kalındığı, verilerin normal dağıldığı görülmüştür. Sonrasında ölçek ifadelerinin demografik değişkenlere göre fark yaratıp yaratmadığı sorgulanmış ve bu nedenle t-Testi ve Anova fark testleri yapılmıştır. Buna göre iş yaşam dengesi ölçeği demografik değişkenlere göre farklılık göstermezken, tükenmişlik 20-35 yaş aralığındaki katılımcılarda $(3,97)$ daha yoğun hissedilmektedir. Yaşam doyumunun ise evli olan turist rehberlerinde daha yüksek $(5,03)$ hissedildiği belirlenmiştir.

Ölçek yapılarının açıklanması ve doğrulanması için öncelikle açıklayıcı faktör analizi ardından doğrulayıcı faktör analizi yapılmıştır. Sonucunda, ölçek yapılarının literatürle uyumlu olduğu, iş yaşam dengesinin tek faktörle, tükenmişliğin 3 faktörle ve yaşam doyumunun tek faktörle açıklandığı görülmüştür. Araştırma amacı doğrultusunda iş yaşam dengesi, tükenmişlik ve yaşam doyumunun birbiriyle olan ilişki ve etki durumunu ortaya koymak için yapısal eşitlik modellemesinden yararlanılıp yol analizi yapılmıştır. Yol analizi ile iş yaşam dengesinin tükenmişlik üzerinde $(-0,403)$ negatif yönlü bir etkisinin olduğu bu durumda iş yaşam dengesi sağlanırsa tükenmişliğin daha az hissedileceğini belirtmek mümkündür. İ̧̧ yaşam dengesi ve tükenmişlik kavramlarını birlikte ele alan çalışmalar (İskender ve Yaylı, 2017; Tuğsal, 2017; Yağcı, 2014; Kanwar, Singh ve Kodwani, 2009; Keeton vd. 2007; Rama Devi ve Nagini, 2013; Putranti, 2018) ile birlikte bu araştırma da bu iki kavramın birbirini etkilediğini ortaya koymuştur. Dengeli bir iş yaşamına sahip olan rehber, aile ve arkadaşlarının ve kendi psikolojik intiyaçlarına cevap verebilecek ve tükenmişlik hissiyle daha az yüz yüze kalacaktır. Tükenmişliğin ise yaşam doyumu üzerinde $(-, 376)$ negatif yönlü bir etkisinin olduğu, tükenmişlik yükselirse yaşam doyumunun daha az 
hissedileceği belirlenmiştir. Ünal, Karlıdağ ve Yoloğlu (2001), Pınar vd. (2015), Avşaroğlu, Deniz ve Kahraman (2005), Demerouti, Bakker ve Bulters (2004), Chan (2011) çalışmaları bu ilişkiyi destekler durumdadır. İş yaşam dengesinin yaşam doyumu üzerinde $(, 253)$ pozitif yönlü etkisinin olduğu, iş yaşam dengesinin sağlanmasının yaşam doyumunu arttıracağını belirtmek mümkündür. TaşdelenKarçkay ve Bakalım (2017), Kuzulu, Kurtuldu ve Özkan (2013), Haar vd. (2014), Cain, Busser and Kang (2018), Bonebright, Clay and Ankenmann (2000), Umer ve Rehman (2013) çalışmaları da iş yaşam dengesi ile yaşam doyumu etkileşimini desteklemektedir.

Turist rehberleri, turizmin yüzü ve tanıtım elçisi konumundadır. Rehberlerin iş yaşam dengesini sağlayabilmesi, tükenmişlik hissinin azaltılması ve yaşam doyumunun arttırıması, rehberlerin verdikleri hizmetin kalitesini ve turist memnuniyetini etkileyecektir. Verilen hizmet kalitesinin artmasıyla hem rehber kendi kazancını etkileyecek hem de acente adına turist memnuniyeti sağlayacak ve ülkeye daha fazla turist gelmesine aracı olacaktır. Bu nedenle hem rehberlerin hem acentelerin tur programlarını organize ederken denge kurulmasına dikkat edilmeli, rehberler tükenmişlik hissini azaltmak için kendilerine, aile ve arkadaşlarına vakit ayırabilmelidir. $\mathrm{Bu}$ araştırma nihayetinde rehberlerin iş yaşam dengesi kurabilmesi için oluşturulmuş öneriler şu şekildedir:

- İş ve yaşam alanlarını rol sentezi yaklaşımıyla birbirleriyle uyumlu hale getirebilirler,

- İş ve özel yaşam alanlarındaki rollerini paylaşma yoluna gidebilirler,

- İş ve yaşam alanlarında rollerin gerekliliklerini yerine getirmede zorlanan rehber, aile, arkadaş veya yakın çevresinden sosyal destek talebinde bulunabilir.

İşverenler ise çalışma planlarını, tur planlamalarını özel durumu olan rehberlerin fikrini alarak oluşturabilirler ve iş yaşam programları çerçevesinde rehberlere hukuki, tıbbi destek sağlayabilirler, özel sigorta yaptırabilirler.

Rehberlerin tükenmişlik düzeylerini azaltmak için bireysel özelliklerine uygun iş seçimi yapmalı, yoğun tempoda çalışılıyorsa işe kısa süreli ara vermeli, pozitif düşünme yeteneği geliştirmeye çalışılmalı, stres yönetimi sağlanmalı ve dinlenmek için vakit ayırılabilmelidir. Meslek odaları ve iş verenler, rehberlerin kendilerini eksik gördüğü alanlarda geliştirilmesi için alana özgü eğitimler, seminerler düzenlemeli, zorlu dönemlerde mali ve sosyal destek sağlamalıdır.

Yapılan araştırma ile literatüre rehberlik mesleğinin iş yaşam dengesi, tükenmişlik düzeyive yaşam doyumu kavramlarının açıklanması, araştırıması ile ilgili kazanımlar sağladığı belirtilebilir. Kavramsal olarak alan yazına belirtilen konularda değer sağlanmış ayrıca pratik olarak sektöre, paydaşlara kazanım sağlanmıştır. Paydaşlar ve özellikle meslek odaları açısından, rehberlerin içinde bulundukları duygu durum halinin anlaşılması ve bu yönde iletişim ve etkileşim kanallarının açık tutulması ile karşılıklı hizmet alışverişinin daha verimli olacağını belirtmek mümkündür.

$\mathrm{Bu}$ çalışma 2020 yılında yaşanan Covid-19 salgını nedeniyle planlanan örneklem sayısına ulaşılamaması nedeniyle sınırlı kalabilmektedir. Covid-19 salgın döneminin sona ermesi ve normal çalışma düzenine geçilmesiyle rehberlerin iş yaşam dengesine, tükenmişlik veya yaşam doyumuna yönelik değerleri farklılık gösterebilir. Normal çalışma düzenine geçilmesiyle daha fazla örneklem sayısına ulaşııması ve farklı değişkenler eklenmesiyle ileriki dönem çalışmaların alana katkı sağlaması mümkündür. 


\section{Kaynakça}

Alrawadieh, Z., Çetin, G., Dinçer, M.Z. ve İstanbullu Dinçer, F. (2018).Exploring Quality Of Work Life And Life Satisfaction Of Tour Guides: An Emotional Labor Perspective. 8 Th Advances in Hospitality And Tourism Marketing And Management (Ahtmm) Conference Proceedings, 25-29 June, Bangkok-Thailand.

Alrawadieh, Z., Çetin, G., Dinçer, M.Z., ve İstanbullu Dinçer, F. (2020). The impact of emotional dissonance on quality of work life and life satisfaction of tour guides. The Service Industries Journal, 40 (1-2), 50-64.

Altay, H. (2009). Antakya ve İskenderun Otel Çalışanlarının Tükenmişliği ve İş Tatmini Üzerine Bir Araştırma. Mustafa Kemal Üniversitesi Sosyal Bilimler Enstitüsü Dergisi. 6 (12), 1-17.

Appleton, S. ve Song, L. (2008). Life Satisfaction İn Urban China: Components And Determinants. World Development, (36), 11.

Ardıç, K., Polatçı, S. (2009). Tükenmişlik Sendromu ve Madalyonun Öbür Yüzü: İşle Bütünleşme.Erciyes Üniversitesi Iktisadi ve Idari Bilimler Fakültesi Dergisi, (32), 21-46.

Arı, G. S. ve Bal, E. Ç. (2008). Tükenmişlik Kavramı: Birey ve Örgütler Açısından Önemi. Yönetim ve Ekonomi, 15 (1), 131-148.

Avşaroğlu, S. Denız, M.E., Kahraman, A. (2005). Teknik Öğretmenlerde Yaşam Doyumu, İş Doyumu ve Mesleki Tükenmişlik Düzeylerinin İncelenmesi. Selçuk Üniversitesi Sosyal Bilimler Enstitüsü Dergisi, (14), 115-129.

Baltacı, A. (2018). Nitel Araştırmalarda Örnekleme Yöntemleri ve Örnek Hacmi Sorunsalı Üzerine Kavramsal Bir İnceleme. Bitlis Eren Üniversitesi Sosyal Bilimler Enstitüsü Dergisi, 7(1), 231-274.

Bonebright, C. A., Clay, D. L.,Ankenmann, R. D. (2000). The Relationship Of Workaholism With Work-Life Conflict, Life Satisfaction, And Purpose In Life. Journal Of Counseling Psychology, 47(4), 469-477.

Brough, P., Tımms, C., O'drıscoll, M.P., Kallıath, T., Siu, O., Sit, C. \& Lo, D. (2014). Work-Life Balance: A Longitudinal Evaluation Of A New Measure Across Australia And New Zealand Workers. The International Journal Of Human Resource Management, 1-21.

Büyüköztürk, Ş. (2011) . Sosyal Bilimler İçin Veri Analizi El Kitabı. Pegem Yayınları, Ankara.

Cain, L., Busser, J. And Kang, H.J. (2018). Executive Chefs' Calling: Effect On Engagement, Work-Life Balance And Life Satisfaction. International Journal Of Contemporary Hospitality Management, 30 (5), 2287-2307.

Ceyhan, A. A., Sılığ, A. (2005). Banka Çalısanlarının Tükenmislik Düzeyleri ile Uyum Düzeyleri Arasındaki Iliskiler. Sosyal Bilimler Dergisi, (2), 43-56.

Chan, D. W. (2011). Burnout And Life Satisfaction: Does Gratitude Intervention Make A Difference Among Chinese School Teachers In Hong Kong?Educational Psychology, 31(7), 809-823.

Comrey, A. L., ve Lee, H. B. (1992). A First Course in Factor Analysis" (2nd Ed.). Hillsdale: Lawrence Erlbaum Associates.

Cortina, J. M. (1993). What İs Coefficient Alpha? An Examination Of Theory And Applications. Journal Of Applied Psychology, 78(1), 98.

Dalkılıç, Sürgevıl O. (2014). Çalışma Hayatında Tükenmişlik Sendromu-Tükenmişlikle Mücadele Teknikleri. 2. Basım. Nobel Akademik Yayıncılık, Ankara.

Diener, E., Emmons, R.A., Larsen, R.J., Grıfın, S. (1985). The Satisfaction With Life Scale. Journal Of Personality Assessment, 49(1), 71-75.

Dikmen, A.A. (1995). İş Doyumu ve Yaşam Doyumu İlişkisi. Ankara Üniversitesi Siyasal Bilgiler Fakültesi Dergisi, 50(3-4), 115-140. 
Demerouti, E., Bakker, A.B. ve Bulters, A.J. (2004). The Loss Spiral Of Work Pressure, Work-Home İnterference And Exhaustion: Reciprocal Relations In A ThreeWave Study. Journal Of Vocational Behavior, 64, 131-49.

Ergin, C. (1995). Sağlık Personelinin İş Anlayışları ve İş Tutumları Araştırması. T.C. Sağlık Bakanlığı Sağlık Projesi Genel Koordinatörlüğü Yayını, Ankara.

Fairllie, P. (2004). Work-Life Issues: An EAP's Perspective. Insights from the Warren Shepell Research Group, http://www.warrenshepell.com/research/latest.asp, 05.08.2019.

George, D., ve Mallery, M. (2010) . Spss For Windows Step By Step: A Simple Guide And Reference. 17.0 Update (10a Ed.) Boston: Pearson.

Guest, D. E. (2002). Perspectives On The Study Of Work-Life Balance.Social Science Information Sage Publications, 41(2), 255-279.

Hsieh, H.H., Chang, C.M., Huang, H.C., Chen, K.C. (2016). Identifications Of The Key Impacting Factors On Hotel Workers' Burnout: A Comparison Of Ragin's Fsqca And Pls-Sem Analysis. The International Journal Of Organizational Innovation, 9(2), 260-270.

Haar, J. M., Russo, M., Suñe, A., ve Ollıer-Malaterre, A. (2014). Outcomes Of WorkLife Balance On Job Satisfaction, Life Satisfaction And Mental Health: A Study Across Seven Cultures. J. Vocat. Behav. 85, 361-373.

Hair, J. F., Black, W. C., Babin, B. J., Anderson, R. E., Tatham, R. L. (2013). Multivariate Data Analysis. Pearson Education Limited.

İskender, A. ve Yaylı, A. (2017). İşgörenlerin İş ve Serbest Zaman Çatışma Düzeyleri ile Mesleki Tükenmişlik ve Yaşam Tatmini İlişkisi: Ankara'daki 4-5 Yıldızı Otel Çalışanları Üzerine Bir Uygulama. Manas Sosyal Araştırmalar Dergisi, 6 (1), 95112.

Kanwar, Y.P.S., Singh, A.K. ve Kodwanı, A. D. (2009). Work-Life Balance And Burnout As Predictors Of Job Satisfaction In The It-Ites Industry Vision. The Journal Of Business Perspective, 13 (2).

Keeton, K., Fenner, D. E., Johnson, T.R.B., Hayward, R.A. (2007). Predictors Of Physician Career Satisfaction, Work-Life Balance, And Burnout. Obstetrıcs \& Gynecology, 109 (4), 949-955.

Kline, B. R. (2011). Principles And Practise Of Structural Equation Modelling. New York/London: The Guilford Press.

Kara, F. M., Kelecek, S. ve Aşçı, F.H. (2014). Sporcu Eşlerinin Yaşam Doyumu ve Yalnızlık Düzeylerinin İncelenmesi. Spor Bilimleri Dergisi Hacettepe J. Of Sport Sciences, 25 (2), 56-66.

Kuzulu, E., Kurtuldu, S. ve Özkan G. V. (2013). İş Yaşam Dengesi ile Yaşam Doyumu İlişkisi Üzerine Bir Araştırma. Sakarya İktisat Dergisi, 2(5).

Küçükusta, D. (2007). Konaklama İşletmelerinde İş-Yaşam Dengesi Sorunları ve Çözüme Yönelik Yaklaşımlar.Dokuz Eylül Üniversitesi Sosyal Bilimler Enstitüsü Dergisi, 9 (3), 243-269.

Maslach, C. ve Jackson, S. E. (1981). The Measurement Of Experienced Burnout. Journal Of Occupational Behavior, 2,99-113.

Maslach, C., Schaufeli, W. B. and Leiter, M. P. (2001). Job Burnout. Annual Review Psychology, 52, 397-422.

Meydan, C.H. ve Şeşen, H. (2015). Yapısal Eşitlik Modellemesi Amos Uygulamaları. Detay Yayıncılık, 2.Baskı, Ankara.

Nunnally, J. C. (1994). Psychometric Theory3e. Tata Mcgraw-Hill Education.

Rama Devi, V. ve Nagini, A. (2013). Work-Life Balance And Burnout As Predictors Of Job Satisfaction In Private Banking Sector. Skyline Business Journal, 1, 50-56.

Rutherford, B. N., Hamwi, G. A., Friend, S. B. ve Hartmann, N. N. (2011). Measuring Salesperson Burnout: A Reduced Maslach Burnout Inventory For Sales 
Researchers. Journal Of Personal Selling \& Sales Management, 31 (4), 429440.

Putranti, H. R. D. (2018). Organizational Commitment Of Hospital Nurses: An Empirical Study On Work-Life Balance And Burnout Management. European Researcher. Series A, 9(3) 235-248.

Pınar, Ş.E, Bilgiç, D., Demirel, G., Akyüz, M.B., Karatepe, C. ve Sevım D. (2015). Sağlık Alanlarında Okuyan Üniversite Öğrencilerinin Tükenmişlik ve Yaşam Doyumları Arasındaki İlişki. Taf Preventive Medicine Bulletin, 14(4), 284-292.

Shukla, A., ve Srivastava, R. (2016). Development Of Short Questionnaire To Measure An Extended Set Of Role Expectation Conflict, Coworker Support And Work-Life Balance: The New Job Stress Scale. Cogent Business \& Management, 3(1), 119.

Tabachnick, B.G. ve Fidell, L.S. (2013). $\quad$ Using Multivariate Statistics. (Sixth Ed.) Pearson, Boston.

Taşdelen-Karçkay, A., and Bakalım, O. (2017). The Mediating Effect Of Work-Life Balance On The Relationship Between Work-Family Conflict And Life Satisfaction. Australian Journal Of Career Development, 26(1), 3-13.

Tümkaya, S., Çam, S. ve Çavuşoğlu, İ. (2009). Tükenmişlik Ölçeği Kısa Versiyonu'nun Türkçe'ye Uyarlama, Geçerlik ve Güvenirlik Çalışması. Ç.Ü. Sosyal Bilimler Enstitüsü Dergisi,18 (1), 387-398.

Tuğsal, T. (2017). İs-Yaşam Dengesi, Sosyal Destek ve Sosyo-Demografik Faktörlerin Tükenmişlik Üzerindeki Etkisi. (Yayınlanmamış Doktora Tezi), İstanbul Ticaret Üniversitesi Sosyal Bilimler Enstitüsü, İstanbul.

Umer, R. ve Rehman, M.Z. (2013). Impact Of Work Life Balance And Work Life Conflict On The Life Satisfaction Of Working Women: A Case Study Of Higher Education Sector Of Twin Cities Of Pakistan. Academic Research International, 4 (5), 445-458.

Ünal, S., Karlıdağ, R. ve Yoloğlu S. (2001). Hekimlerde Tükenmişlik ve İş Doyumu Düzeylerinin Yaşam Doyumu Düzeyleri ile Iliş̧kisi. Klinik Psikiyatri, 4, 113-118.

Yağcı, E. (2014). Konaklama İşletmelerinde Kurumsallaşmanın İş Yaşam Dengesi Aracılığıyla Tükenmişlik Düzeyine Etkisi: Beş Yıldızı Otel Genel Müdürleri Üzerine Bir Uygulama. (Yayınlanmamış Doktora Tezi), Akdeniz Üniversitesi Sosyal Bilimler Enstitüsü, Antalya.

Yıldız, S. (2020). Turizm Endüstrisinde Paylaşım Ekonomisi Platformları Kullanım Motivasyonlarının Belirlenmesi ve Paylaşım Ekonomisi Kabul Modeli Önerisi: Konaklama ve Ulaştırma Hizmetleri Üzerine Bir Araştırma. (Yayınlanmamış Doktora Tezi), İstanbul Üniversitesi Sosyal Bilimler Enstitüsü, İstanbul.

Wong, S. C. ve Ko, A. (2009). Exploratory Study of Understanding Hotel Employees' Perception on Work-Life Balance Issues. International Journal of Hospitality Management, 28, 195-203 
Tarih ve Sayn: 06/08/2020-103972

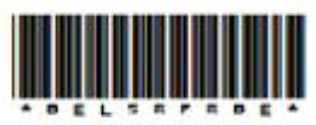

T.C.

ISTANBUL ÜNIVERSİTESI REKTÖRLÜĞÜ

Sosyal ve Beșeri Bilimler Araștırmaları Etik Kurulu

Başkanlığı

Say1 :35980450-663.05-

Konu Ö̈mur CETINNKAYA

\section{Sayun Öznur ÇETINKAYA}

İigi : 01.07.2020 tarih ve 29867 sayıl başvurunuz.

Sorumlu araştmelığmı üstlendiğiniz 2020/83 dosya numaralı "Profesyonel Turist Rehberlerinin İş-Yaşam Dengesi ve Tükenmişlik Düzeylerinin Calışma Motivasyonuma Etkisi" başlıklı çalışma, Kurulumuzun 10.07.2020 tarih ve 08 saylh toplantısmda görüşūlerek etik yönden uygun bulummuş olup, karar ekte sumulmuştur.

Bilgilerinizi rica ederim. 